\title{
AS AVENTURAS DO MARXISMO NO BRASIL
}

\author{
Ricardo Musse*
}

\begin{abstract}
A meditação acerca da importância e do lugar do marxismo na sociedade brasileira - seja na vida política e social, seja na produção intelectual e cultural - adquiriu uma via privilegiada com a conclusão da obra coletiva História do marxismo no Brasil. Um inventário, mesmo que precário, de suas lacunas e superposições também abre espaço para um balanço da produção bibliográfica sobre o marxismo brasileiro. A partir disso, torna-se possível destacar estruturas e tendências em seu desenvolvimento histórico. Palavras-chave: Marxismo brasileiro. Partido Comunista do Brasil (PCB). Partido dos Trabalhadores (PT). História do marxismo no Brasil.
\end{abstract}

Com a publicação, em 2007, de seu sexto e último volume, História do marxismo no Brasil consolida-se como o mais ambicioso e completo programa já realizado de reconstituição da história do marxismo brasileiro. Superando os percalços de sempre, cumpre-se assim, com inegável êxito, o projeto editorial coletivo delineado pelo grupo de trabalho "Partidos e Movimentos de Esquerda”, então vinculado à Associação Nacional de Pós-Graduação e Pesquisa em Ciências Sociais (Anpocs), no longínquo ano de $1988 .{ }^{1}$

Um exame do conjunto possibilita um inventário, ainda que precário, de lacunas e superposições da produção bibliográfica sobre o tema, posto que os organizadores adotaram como critério principal convidar autores de pesquisas já concluídas no âmbito da reflexão histórica sobre o marxismo brasileiro. Propicia ainda ocasião para uma meditação, mesmo

* Universidade de São Paulo (USP), Faculdade de Filosofia Letras e Ciências Humanas, Departamento de Sociologia. Av. Prof. Luciano Gualberto, 315. Cep: 05021-010. Butantã - Sao Paulo, Sao Paulo - Brasil.rmusse@usp.br

${ }^{1} \mathrm{O}$ primeiro volume, coordenado por João Quartim de Moraes e Daniel Aarão Reis, foi editado em 1991, pela Paz e Terra. Atualmente a íntegra da coleção é publicada pela Editora da Unicamp. que panorâmica, acerca do impacto do marxismo na sociedade brasileira seja no que tange à vida política seja sobre a produção intelectual e cultural.

Convém antes relembrar a ambiguidade inerente ao termo "marxismo", cujo significado remete a dois corpus políticos e intelectuais distintos, porém entrelaçados. A mesma palavra designa tanto a obra teórica e a participação política de Karl Marx e Friedrich Engels - num leque que se estende da gênese do materialismo histórico aos esforços que fizeram para direcionar os então emergentes partidos de massas que se congregaram na Segunda Internacional -, como a linhagem constituída pela adição a esse legado da contribuição política e intelectual de seus seguidores, assim como do arsenal prático e teórico desenvolvidos por diversos movimentos e partidos operários. ${ }^{2}$

Na primeira acepção, a própria definição do termo delimita um território que nunca se tornou incontroverso. Duas das principais polêmicas atinentes ao materialismo históri-

\footnotetext{
${ }^{2}$ Para um retrospecto da origem do termo marxismo e da recusa de Marx e Engels a convalidá-lo, conferir Marx e o marxismo de Georg Haupt, 1982.
} 
co vinculam-se, mesmo que indiretamente, à determinação de suas balizas. A exaustiva discussão acerca do estatuto da obra do jovem Marx tem como pano de fundo a aferição do momento em que Marx tornou-se "marxista". A querela sobre o "último Engels", por sua vez, não pode ser descolada da tentativa de estabelecer o ponto terminal do processo de constituição da doutrina marxista.

O marxismo, na segunda acepção do termo - o estabelecimento de uma tradição teórica e prática que se mantém ativa e vivificada décadas depois da morte de seus fundadores -, surgiu a partir de uma série de procedimentos adotados pelo último Engels. As providências por ele sistematizadas desembocaram em dois movimentos antagônicos e embaralhados - os esforços de divulgação e de ampliação da doutrina de Marx. ${ }^{3}$

A história do marxismo no Brasil desenvolveu-se no plano definido por essas duas coordenadas. De um lado, pode ser considerada como um exemplar típico do processo que Franco Andreucci (1982) denominou como "difusão e vulgarização" do marxismo: a conjugação de "expansão e empobrecimento, difusão e esquematização", seja por conta do choque e de sua inevitável combinação com outras ideias (socialistas ou não), decorrente 농 de sua propagação em escala planetária; seja política das ascendentes estruturas organizacionais da classe operária - associações, sindisotos, cooperativas, partidos. ${ }^{4}$ Por outro lado, embora as contribuições brasileiras para a ampliação do repertório de interpretações, com× plementações e atualizações da obra de Marx \& sejam escassas, o marxismo nacional, desde 舒 seus primórdios, sempre procurou compreen$\rightarrow$

đิ ${ }^{3}$ Um breve relato das providências adotadas por Engels pode ser encontrado em "O primeiro marxista", de Ricardo Musse (2000),

œ 4 Ver "A difusão e a vulgarização do marxismo", de Franco

Andreucci (1982). Acerca da disseminação do marxismo,

ک nesse período, confira também de Eric Hobsbawm (1992,

○ 1982). A era dos impérios (1875-1914) ou "A cultura européia e o marxismo entre o século XIX e o século XX".

* Optamos por destacar os títulos dos artigos com o uso de aspas e os títulos dos livros com o itálico. der a especificidade da sociedade local, o que não deixou de concorrer para a expansão do escopo da doutrina.

A delimitação das fronteiras do marxismo, nessa segunda acepção do termo, tornouse palco de acirrada luta e concorrência entre as diversas correntes nas quais essa tradição se bifurcou após o fim da Segunda Internacional, em agosto de 1914. As redefinições do campo marxista, em geral, embutiam sorrateiras tentativas de deslegitimar grupos e tendências adversárias. Os organizadores dessa coleção, em consonância com a conjuntura marcada pelo enfraquecimento do marxismo e pela distensão e aproximação entre inimigos de outrora, souberam evitar os riscos de indicar uma de suas linhagens como mais autêntica ou verdadeira, um traço nem sempre presente ao longo da história do marxismo no país.

Uma vez superada a armadilha de tentar afirmar ou mesmo privilegiar, dogmaticamente, uma dentre suas várias vertentes, a questão da delimitação do território do marxismo brasileiro reaparece sob nova roupagem. A dificuldade, inerente a uma tradição de pouco viço e capilaridade excessiva, desloca-se para a determinação do que seria propriamente marxista na prática dos movimentos sociais e dos partidos políticos, nas teorias de interpretação do país, na produção universitária ou ainda no âmbito da arte e da cultura nacionais.

Nesse cenário, o hábito, em princípio sensato, de considerar como pertencente ao campo do marxismo as teorias, programas, movimentos e acontecimentos que reivindicam explicitamente sua filiação mostra-se insuficiente. Não é difícil identificar manifestações - muitas delas mais interessantes e importantes que as assumidamente marxistas - que, por conta de situações adversas ou por desconhecimento de suas fontes, não se reivindicam como tal. Assim, muitas vezes, é preciso discernir, no universo mais amplo de uma história da esquerda, sinais da influência do marxismo em manifestações que não reconhecem seu impacto. Essa complicação exige 
um cuidadoso esforço para discernir as intersecções entre o marxismo e a cultura local, um procedimento muitas vezes obliterado pelos pesquisadores. $^{5}$

O marxismo aportou tardiamente no Brasil. Seja como teoria ou prática política, desembarca efetivamente apenas em 1922, com a fundação do Partido Comunista, um acontecimento que deve ser creditado sobretudo ao impacto no país da Revolução Russa de 1917. ${ }^{6}$

Na coleção, a proto-história do marxismo no Brasil foi abordada em dois artigos. ${ }^{7}$ Evaristo de Moraes Filho cataloga as referências, simpáticas ou hostis a Marx, num trabalho pioneiro e erudito, mas de pouca valia. ${ }^{8} \mathrm{O}$ artigo de Claudio H. M. Batalha contém muitas informações adicionais, atestando o quanto avançou a pesquisa sobre o tema, com a especialização universitária, no decorrer de uma geração. H. M. Batalha, no entanto, menciona apenas de passagem a questão principal: por que o marxismo, reivindicado oficialmente pela Segunda Internacional desde 1890 e em processo acelerado de disseminação mundial, teve uma acolhida tão esporádica no Brasil antes de $1922 ?^{9}$

${ }^{5}$ Considerações bastante pertinentes sobre as premissas necessárias à constituição do objeto de pesquisa "esquerda brasileira" podem ser encontradas em "Contribuições para uma história da esquerda brasileira”, de Marco Aurélio Garcia (1986). Um amplo panorama de uma história da esquerda brasileira foi delineado nos três volumes de As esquerdas no Brasil, organizados por Jorge Ferreira \& Daniel Aarão Reis (2007).

${ }^{6} \mathrm{Na}$ coleção, a influência da Revolução Russa na formação do Partido Comunista Brasileiro foi destacada por Marcos Del Roio (2007) em "O impacto da revolução russa e da internacional comunista no Brasil”. O livro clássico sobre o assunto é $O$ ano vermelho de Luiz Alberto Muniz Bandeira (1967).

${ }^{7}$ Para um comentário, livro a livro, sobre os seis volumes da coleção, em um eixo diferente da exposição cronológico-temática abaixo, conferir "O legado de Marx no Brasil", de Ricardo Musse (2008).

8 “A proto-história do marxismo no Brasi”l. de Evaristo Moraes Filho (2007) trata-se, na realidade, de uma versão condensada da introdução da antologia que organizou sobre o pensamento socialista no Brasil: $O$ socialismo brasileiro (1998).

${ }^{9}$ Conferir, de Claudio H. M. Batalha (1995), "A difusão do marxismo e os socialistas brasileiros na virada do século
A bibliografia sobre os comunistas nos anos 1920 é substancialmente mais rica e polêmica. O artigo de Marcos Del Roio sobre o PCB nesse período, ${ }^{10}$ apesar de convencional, não tem como contornar tópicos que se tornaram obrigatórios como a tensão entre sindicalistas e intelectuais, a relação do partido com a Internacional Comunista, sua posição diante do tenentismo e o debate sobre os erros e acertos do conjunto de estratégias implementadas durante a conturbada conjuntura que culminou na Revolução de 1930. ${ }^{11}$

A produção intelectual dos militantes do PCB antes de 1930 foi apresentada, no quarto volume da série, por Angelo José da Silva. Contempla os esforços teóricos de Astrojildo Pereira, Mario Pedrosa e Octavio Brandão, valorizando e detendo-se mais no livro desse último, Agrarismo e industrialismo (2006). O artigo, estranhamente, não menciona $A$ derrota $d a$ dialética, de Leandro Konder (1988). ${ }^{12}$ Apesar do tom polêmico, trata-se sem sombra de dúvida da obra mais importante sobre a recepção,

XIX”. Claudio Batalha continuou concentrando suas pesquisas sobre o movimento operário e os militantes socialistas no período da primeira República. Sua mais recente publicação é um dicionário do movimento operário, que se estende do século XIX aos anos 1920: Dicionário do movimento operário: Rio de Janeiro do século XIX aos anos 1920, militantes e organizações (2009). Entre a antologia pioneira de Evaristo de Moraes Filho (1998) e as pesquisas capitaneadas por Batalha $(1995,2009)$ cabe destacar a coletânea de documentos recolhidos em A classe operária no Brasil, documentos (1989 a 1930), de Paulo Sérgio Pinheiro \& Michael Hall (1979).

10 Ver, de Marcos Del Roio (2002), "Os comunistas, a luta social e o marxismo (1920-1940)”. Informações e análises sobre os anos iniciais do PCB podem ser encontradas nos livros de Astrojildo Pereira (1962, 1979, 1980), especialmente em Formação do PCB (1922-1928), Ensaios históricos e políticos e Construindo o PCB (1922-1924).

${ }^{11}$ Entre os livros que ajudaram a cristalizar a importância desses temas não há como deixar de mencionar Política e trabalho no Brasil: dos anos vinte a 1930 de Paulo Sérgio Pinheiro (1975) e O silêncio dos vencidos de Edgar Salvadore De Decca (1982). Para um balanço desses debates e uma análise discordante conferir os livros de Michel Zaidan Filho (1988, 1989): O PCB e a Internacional Comunista: $1922-1929$ e Comunistas em céu aberto, 1922-1930 e PCB (1922-1929): a busca das origens de um marxismo nacional.

${ }^{12} \mathrm{O}$ artigo de Angelo José Silva (2000), “Tempo de fundadores", discrepa do restante da coleção pela escassez bibliográfica. Não cita, por exemplo, nenhum dos artigos do caderno Memória \& história, n. 1, dedicado a Astrojildo Pereira. Note-se, no entanto, que só depois de sua publicação veio a lume a biografia redigida por Martin Cezar Feijó (2001), O revolucionário cordial. Astrojildo Pereira e as origens de uma política cultural. 
no período entre 1871 e 1930, das ideias de Marx no Brasil. Um dos destaques do livro de Konder (1988) é a demolição exemplar e antológica de Agrarismo e industrialismo (2006). ${ }^{13}$

A conjuntura nacional e internacional no início da década de 1930 fortaleceu o PCB, um pouco à revelia de sua postura ante a crise de 1929 e a Revolução de 30. Uma contraprova disso foi a adesão ao partido de importantes quadros do tenentismo, da intelectualidade burguesa e do modernismo artístico, dentre os quais se sobressaem os nomes de Luiz Carlos Prestes, Caio Prado Jr. e Oswald de Andrade. A acolhida concedida a cada um deles - as desventuras de Oswald, ${ }^{14}$ as relações conflituosas de Caio Prado com o comitê central, ${ }^{15}$ o posto de comando concedido a Prestes ${ }^{16}$ - é reveladora da hierarquia que estruturou o Partido Comunista Brasileiro desde então como "uma confluência de trabalhadores, intelectuais e militares do exército", na fórmula sintética de Francisco de Oliveira. ${ }^{17}$

A supremacia de Prestes na luta interna é

${ }^{13}$ O livro A derrota da dialética de Leandro Konder (1988) foi concebido e rascunhado na segunda metade da década de 1960, numa conjuntura marcada pela preocupação dos intelectuais de esquerda em revisar a história do comunismo no Brasil, na busca de explicações para a derrota de 1964. Sua versão final, no entanto, sob a forma de tese de doutoramento, data de 1986 . Por meio de um relato pormenorizado da recepção do marxismo no Brasil, entre 1871 e

1929, Konder procura compreender, entre outras coisas, a

$\stackrel{20}{\rightarrow}$ afinidade eletiva que fez com que o PCB comungasse com

จ tanto ardor a doutrina e a prática política stalinista.

$\dot{\circ}{ }^{14} \mathrm{Cf}$. O salão e a selva: uma biografia intelectual de Oswald de Andrade de Maria Eugenia Boaventura (1996).

${ }^{15}$ Cf. Caio Prado Júnior: O sentido da revolução de Lincoln 10

F 16 Cf. Prestes: Lutas e autocríticas de Dênis Moares e \& Francisco Viana (1982); Vida de Luiz Carlos Prestes: o + cavaleiro da esperança de Jorge Amado (1945); e Prestes e 2. a revolução social de Abguar Bastos (1986).

 \& marxismo e política no Brasil”, de Francisco de Oliveira - (2006). São inúmeros os livros que tratam do PCB no pe-

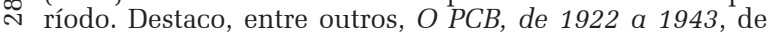

$>$ Edgar Carone (1982); O partido comunista brasileiro: 1922-

ثี 1964, de Eliézer Pacheco (1984); Contribuição à história

do PCB, de Nelson Werneck Sodré (1984); A classe operá-

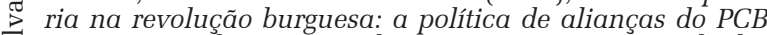
ஸึ (1928-1935), de Marcos Del Roio (1990); Estratégias da ilu- são: a revolução mundial e o Brasil, 1922-1935, de Paulo Sérgio Pinheiro (1991); A esquerda Positiva: as duas almas

of do partido comunista (1920-1964), de Gildo Marçal Bran-

- dão (1992); Sinfonia inacabada: a política dos comunistas

no Brasil, de Antonio Carlos Mazzeo (1999) e Da insurreição armada (1935) à "União Nacional" (1938-1945): a viU rada tática na política do PCB, de Anita Leocadia Prestes. concomitante à conversão do PCB em braço local da Internacional Comunista. A configuração resultante do embate entre o influxo externo e as demandas da conjuntura nacional recebeu a devida atenção em História do marxismo no Brasil. No primeiro volume, João Quartim de Moraes (2003) procura identificar, a partir de uma clivagem entre o marxismo de Stálin e o leninismo, a influência do assim chamado marxismo-leninismo na teoria e na prática do PCB, a partir dos anos 1930. ${ }^{18}$ As discrepâncias e convergências entre as diretrizes externas e as exigências locais foram retomadas em várias passagens de um artigo do segundo volume, no qual o mesmo Quartim de Moraes procura determinar as coordenadas que moldaram a ação política dos comunistas brasileiros entre 1930 e $1970 .^{19}$

É também sobre o "duplo prisma” do nacional e do internacional que Dainis Karepovs e José Castilho Marques Neto reconstituem a trajetória da Oposição de Esquerda - liderada por Mário Pedrosa, Rodolfo Coutinho e Lívio Xavier -, inicialmente fração do PCB e em seguida embrião de uma seqüência de organizações trotskistas. ${ }^{20}$

Algumas das maiores lacunas da coleção referem-se a esse período. O justificado temor de vício personalista não justifica a ausência de um perfil de Luiz Carlos Prestes, o mais destacado entre os jovens "tenentes", o comandante geral da Coluna Prestes, o militar que inesperadamente aderiu ao comunismo, o dirigente que liderou por décadas o Partido

${ }^{18}$ Cf. "A influência do leninismo de Stálin no comunismo brasileiro”, de João Quartim de Moraes (2003).

${ }^{19}$ Cf. "A evolução da consciência política dos marxistas brasileiros”, de João Quartim de Moares (1995).

${ }^{20} \mathrm{Cf}$. "Os trotskistas brasileiros e suas organizações políticas (1930-1966)”, de Dainis Karepovs e José Castilho Marques Neto (2002). Estes autores desenvolveram várias pesquisas sobre a história do trotskismo no Brasil: Mário Pedrosa e o Brasil, livro organizado por José Castilho Marques Neto (2001) e Solidão revolucionária: Mário Pedrosa e as origens do trotskismo no Brasil (1993), de sua autoria; Na contracorrente da história: documentos da Liga Comunista Internacionalista, 1930-1933 organizado por de Fúlvio Abramo e Dainis Karepovs (1987); este último também autor de Luta subterrânea: o PCB em 1937-1938 (2003). Conferir ainda O trotskismo no Brasil, 1928-1964 de Osvaldo Coggiola (2003). 
Comunista Brasileiro. ${ }^{21}$ Cabe notar ainda a inexistência de um artigo dedicado ao exame da formação e dos propósitos da Aliança Libertadora Nacional (ALN), assim como do teor da insurreição de novembro de 1935, um levante militar que pode ser considerado tanto "a última revolta tenentista" como uma tentativa revolucionária ao molde da Internacional Comunista. ${ }^{22}$ Por fim, não há como deixar de observar que pouco se discute a posição do PCB e dos sindicatos a ele vinculados diante da nova legislação trabalhista implantada gradualmente por Getúlio Vargas no primeiro decênio de seu governo, uma questão decisiva para a compreensão da relação nem sempre direta entre a classe, o movimento operário e o Partido Comunista Brasileiro. ${ }^{23}$

Com o término da Segunda Guerra, por conta de sua resistência e luta contra o Estado Novo, mas também graças à vitória da União Soviética sobre o nazismo, inicia-se a era áurea do PCB, um período de proeminência encerrado repentinamente pelo golpe militar de 1964 . Nesses anos, a força de sua influência favoreceu a disseminação do marxismo em amplos setores da vida política, intelectual e cultural do país. ${ }^{21}$ Não deixa de impressionar a escassez de pesquisas sobre
a trajetória política de Luiz Carlos Prestes. No que tange a
esse período, uma exceção são os dois últimos capítulos de
Estratégias da ilusão: a revolução mundial e o Brasil, 1922-
1935, de Paulo Sérgio Pinheiro (1991) e o livro de Anita
Leocádia Prestes (1997) Luiz Carlos Prestes e a Aliança
Nacional Libertadora: os caminhos da luta antifascista no
Brasil (1934-1935). Sobre a participaçâo dos militares nos
agrupamentos de esquerda, confira os dois livros de João
Quartim de Moraes (1991, 1994): A esquerda militar no
Brasil: da conspiraçâo republicana à república dos tenen-
tes e A esquerda militar no Brasil: da Coluna à Comuna.

${ }^{22}$ A principal fonte sobre a insurreição de 35 ainda são as memórias dos participantes do evento. Dentre as pesquisas mais abrangentes cabe destacar 1935: A revolta vermelha, de Hélio Silva (1969); O comunismo no Brasil, de John W. F. Dulles (1985); Novembro de 1935: meio século depois, organizado por José Nilo Tavares (1985); A intentona comunista de 1935, de Nelson Werneck Sodré (1986); Estratégias da ilusão: a revolução mundial e o Brasil, 1922-1935, de Paulo Sérgio Pinheiro (1991); Revolucionários de 1935: sonho e realidade, de Marly Vianna (1992) e A esquerda Positiva: as duas almas do partido comunista (1920-1964), de Gildo Marçal Brandão (1992).

${ }^{23}$ Questão presente, no entanto, na bibliografia de esquerda desde o livro clássico de Luiz Werneck Vianna (1976) Liberalismo e sindicato no Brasil. Conferir também Classe operária, partidos e sindicatos no Brasil: da Revolução de 30 até a Aliança Nacional Libertadora, de Ricardo Antunes (1982) e Sindicatos e democratização, de Ricardo Maranhão (1979).
O Partido manteve sua oscilação entre as demandas da classe operária e os ritmos ditados pelo movimento comunista internacional. Por um lado, arrefeceu seu ímpeto insurrecional, motivado por sua exitosa performance eleitoral no breve intervalo da legalidade, mas também repercutindo a integração social do proletariado no auge do nacional-desenvolvimentismo. Por outro lado, adota um comportamento político errático - apóia Getúlio no estertor do seu período ditatorial, engajandose na fracassada campanha do "queremismo", mas opõe-se radicalmente ao seu segundo governo (1950-1954), mesmo quando este adota uma inflexão popular e nacionalista -, equívocos só reconhecidos na "Declaração sobre a política do PCB”, de março de 1958, quando finalmente, em sintonia com sua prática cotidiana, adota um programa antiimperialista, democrático e nacional, no esquadro de uma "revolução burguesa".

O artigo de Daniel Aarão Reis, no quinto volume, relata, passo a passo, a trajetória do PCB entre o congresso de reconstrução do Partido em 1943 - a "Conferência da Mantiqueira" - e o golpe militar de 1964, procurando compreender a flutuação de sua linha política à luz do dilema "reforma ou revolução". ${ }^{24}$ Quartim de Moraes, no terceiro livro, acompanha as análises de conjuntura do PCB entre 1944 e 1954. Atribui seu movimento pendular, em larga medida, ao impacto no interior do Partido de sua legalização e posterior cassação. ${ }^{25}$ Raimundo

${ }^{24}$ Cf. "Entre reforma e revolução: a trajetória do Partido Comunista no Brasil entre 1943 e 1964", de Daniel Aarão Reis (2002). Sobre a trajetória política do PCB entre 1943 e 1964 conferir também O PCB: 1943-1964, de Edgar Carone (1982); O Partido Comunista Brasileiro: conflito e integraÇão, de Ronald H. Clicote (1982); O Partidão: A luta por um partido de massas (1922-1974), de Moisés Vinhas (1982);
Reforma e revolução: as vicissitudes políticas do PCB, 1954-1964, de José Antonio Segato (1995); e A esquerda Positiva: As duas almas do partido comunista (1920-1964), de Gildo Marçal Brandão (1992).

${ }^{25}$ Cf. "Concepções comunistas no Brasil democrático: esperanças e crispações”, de João Quartim de Moraes (1998). $\mathrm{O}$ artigo destaca que a cassação do registro do PCB, mais que um episódio circunscrito pelo início da Guerra Fria, marca uma atitude de desrespeito à legalidade democrática encetado pelos três poderes. Sobre esse episódio conferir também PCB: processo de cassação de registro (1947), organizado por Luiz de Carvalho Bicalho (1980) e A democracia intolerante: Dutra, Adhemar e a repressão ao Partido Comunista (1946-1959), de Pedro Estevam da Rocha 
Santos, no primeiro volume, destaca, como uma das premissas da "Declaração de Março de 1958", a descompressão da vida partidária resultante da denúncia dos crimes de Stálin por Nikita Khrushchov no XX Congresso do Partido Comunista da União Soviética, em 1956. ${ }^{26}$

Afora o descompasso entre o paulatino processo de integração social do proletariado e sua exclusão da vida política - numa democracia cujo caráter oligárquico tornou-se explícito no episódio de cassação do registro do PCB, assim como em sua posterior manutenção na ilegalidade -, a instabilidade da linha política do Partido Comunista Brasileiro traduzia uma contradição objetiva, inerente ao projeto de uma "Revolução nacional".

O empenho do Partido na organização de uma frente antiimperialista, sua política de alianças poli-classista, em suma, as determinações características de uma proposta de revolução democrático-burguesa direcionava sua ação para transformações no âmbito do capitalismo. A situação mundial no auge da Guerra Fria, no entanto, indicava que eram diminutas as possibilidades de mobilidade no interior do sistema inter-estatal capitalista - em sua hierarquia congelada com poucos países no núcleo orgânico, alguns numa intermediária semi-periferia e a maioria instalada na periferia. A expectativa $\stackrel{20}{5}$ de se obter um "catch-up" mirava, sobretudo, $\stackrel{N}{\circ}$ as experiências de países que tentaram gravitar fora da órbita do sistema capitalista. ${ }^{27}$

Ao mesmo tempo em que afirma sua proeminência no campo da esquerda, particularmente na seara do movimento operário, o PCB perde o monopólio do marxismo. Surgem novas agremiações que + reivindicam também, em maior ou menor medida, o

\& Pomar (2002).

$\stackrel{\infty}{\sim}{ }^{\circ}$ Raimundo Santos (2003), em Crise e pensamento mo-

$>$ derno no PCB dos anos 50, relata os esforços da direção do

કิ PCB para diminuir o impacto no Brasil das resoluções do

XX Congresso, bem como a luta interna desencadeada por $\geqslant$ essa tentativa.

๘ ${ }^{27}$ Análises do sistema inter-estatal ao longo da Guerra Fria, no período do nacional-desenvolvimentismo, podem ser

ઉ encontradas em A ilusão do desenvolvimento, de Giovanni

○ Arrighi (1997); Capitalismo histórico e civilização capita-

lista, de Immanuel Wallerstein (2001) e $O$ vôo da coruja:

para reler o desenvolvimentismo brasileiro, de José Luís ษ Fiori (2003) legado de Marx. O quinto volume da série apresenta uma cobertura abrangente desse novo leque, com estudos pormenorizados das concepções marxistas presentes nas organizações trotskistas, ${ }^{28}$ no Partido Socialista Brasileiro, ${ }^{29}$ na Organização Revolucionária Marxista Política Operária (POLOP) ${ }^{30} \mathrm{e}$ ainda na Ação Popular (AP). ${ }^{31}$

Desde então, a versão exportada pela União Soviética, o assim chamado "marxismo -leninismo”, preponderante até então no país, passa a ter a concorrência de outras vertentes do marxismo. A coleção destaca a presença na esquerda brasileira do trotskismo, ${ }^{32}$ do maoísmo ${ }^{33}$ e do castrismo-guevarismo. ${ }^{34}$ Dentre os "marxistas ocidentais", selecionou os com maior repercussão no Brasil: Antonio Grams-

28 "Os trotskistas brasileiros e suas organizações políticas (1930-1966)”, de Dainis Karepovs e José Castilho Marques Neto (2002). Para um relato mais detalhado da formação e da trajetória política do Partido Operário Revolucionário (POR) conferir À esquerda da esquerda: trotskistas, comunistas e populistas no Brasil contemporâneo (1952-1966), de Murilo Leal (2004).

${ }^{29}$.Cf. "O Partido Socialista Brasileiro e o marxismo (19471965)”, de Margarida Luiza de Matos Vieira (2002). A bibliografia sobre o PSB resume-se a dois livros: Semeando democracia: a trajetória do socialismo democrático no Brasil, de Miracy Barbosa de Sousa Gustin e Margarida Luiza de Matos Vieira (1995). e Socialismo sociável: história da esquerda democrática em São Paulo (1945-1964), de Alexandre Hecker (1998).

${ }^{30}$ Cf. Mattos (2002). Nos últimos anos iniciou-se a publicação no Brasil dos textos e de estudos sobre Ruy Mauro Marini, um dos dirigentes da POLOP: Dialética da dependência, de Ruy Mauro Marini (2000); Ruy Mauro Marini: Vida e obra, organizado por Roberta Traspadini e João Pedro Stedile (2005); e A América Latina e os desafios da globalização: ensaios em homenagem a Ruy Mauro Marini, organizado por Emir Sader e Theotônio Santos (2009).

${ }^{31}$ Cf. "Ação Popular: cristianismo e marxismo”, de Marcelo Ridenti (2002). Na ampla bibliografia sobre a interpenetração entre marxismo e catolicismo no Brasil, tratam especificamente da Juventude Universitária Católica (JUC) e da Juventude Estudantil Católica (JEC), troncos que se fundiram na criação da AP, entre outros: A JUC no Brasil, evolução e impasse de uma ideologia, de José Luiz Sigrist (1982); História da Ação Popular, da JUC ao PC do B, de Aldo Arantes e Haroldo Lima (1984); Cristãos na universidade e na política: história da JUC e da AP, de José Oscar Beozzo (1984); A JUC: os estudantes católicos e a política, de Luiz Alberto Gomes de Souza (1984); e Marxismo e teologia da libertação, de Michael Löwy (1991).

${ }^{32}$ Cf. "Trotsky e o Brasil”, de Dainis Karepovs, José Castilho Marques Neto e Michael Löwy (1995).

${ }^{33}$ Cf. "O maoísmo e a trajetória dos marxistas brasileiros", de Daniel Aarão Reis (2003)

${ }^{34}$ Cf. "A influência da revolução cubana sobre a esquerda brasileira nos anos 1960", de Carlos Alberto de Barão (2003). 
ci, ${ }^{35}$ Georg Lukács ${ }^{36}$ e Louis Althusser. ${ }^{37}$ Não é demasiado reprisar o lamento pela ausência de considerações acerca da recepção local de Jean-Paul Sartre, Walter Benjamin e Herbert Marcuse, cujas obras impactaram extratos da intelectualidade nas mais inesperadas áreas. ${ }^{38}$

Além da co-existência e concorrência entre diferentes variantes do marxismo, sua disseminação maciça nos meios intelectuais e na Universidade contribuiu para dificultar, no período, a delimitação do marxismo brasileiro. Sua influência transborda o escopo do Partido Comunista e até mesmo o âmbito dos filiados à fatia do espectro partidário que reivindica explicitamente essa linhagem.

Para contemplar a multiplicidade das influências do marxismo sobre as interpretações do Brasil e a produção intelectual local, os organizadores da coleção empreenderam várias estratégias, em certa medida complementares. Não foi possível, no entanto, desenvolver nenhuma delas de forma sistemática, dado o estado incipiente das pesquisas.

Primeiro, ensaiou-se uma apresentação da inserção do marxismo nas diferentes áreas do conhecimento, levada a cabo no segundo volume da série. Três artigos temáticos abordam, respectivamente, a política, ${ }^{39}$ a econo-

${ }^{35}$ Cf. "Gramsci no Brasil: recepção e usos”, de Carlos Nelson Coutinho (1998). O artigo comenta em breves pinceladas a recepção de Gramsci no Brasil (à esquerda e à direita; no PCB, nas comunidades da Igreja e no PT). Além disso, apresenta o uso - tanto o já praticado como o que ainda poderá ser feito - das categorias de Gramsci na interpretação da sociedade brasileira.

${ }^{36}$ Cf. "Presença de Lukács na política cultural do PCB e na Universidade", de Celso Frederico (1995). O artigo contém uma exaustiva lista das manifestações explícitas da influência de Lukács sobre uma geração de militantes e intelectuais, tanto filiados como dissidentes do PCB. Apresenta ainda um histórico das traduções de seus textos; relata a aplicação de alguns conceitos de sua lavra, como "via prussiana", ao estudo da sociedade brasileira; e, por fim, comenta sua recepção na Universidade em distintas áreas - na filosofia, na sociologia e na crítica literária.

${ }^{37}$ Cf. "O impacto da teoria althusseriana da história na vida intelectual brasileira”, de Décio Saes (1998). O artigo reconstitui as ideias de Althusser, por meio de uma minuciosa discussão teórica dos conceitos e pressupostos do materialismo histórico.

${ }^{38}$ Para um precioso relato da predileção dos cineastas do Cinema Novo por Walter Benjamin, conferir Em busca do povo brasileiro: artistas da revolução, do CPC à era da TV, de Marcelo Ridenti (2000, p. 95-96).

${ }^{39}$ Cf. "A evolução da consciência política dos marxistas mia $^{40}$ e a filosofia. ${ }^{41}$ Afora os resultados desiguais, esse balanço do impacto do marxismo sobre as ciências humanas no Brasil - por conta da mencionada ausência de pesquisas aprofundadas acerca destes tópicos - desconsiderou as disciplinas em que sua presença é mais visível: a sociologia, a historiografia e os estudos literários.

A segunda estratégia, restrita a um artigo no terceiro volume, propõe-se a analisar em bloco a posição perante o marxismo e o PCB dos dois grupos intelectuais mais representativos do período, o Instituto Superior de Estudos Brasileiros (Iseb) e o "Seminário Marx”. A parte referente ao Iseb, um órgão vinculado diretamente à Presidência da República entre 1955 e 1964, salienta as divergências entre seus membros acerca da viabilidade de uma política de desenvolvimento nacional e da possibilidade de uma revolução "democrática-burguesa" no Brasil. ${ }^{42}$ No que tange ao "Seminário Marx"

brasileiros”, de João Quartim de Moraes (1995). O artigo delineia tanto uma periodização como uma determinação teórica da consciência política dos militantes do PCB entre os anos 1920 e a década de 1970, a partir de uma análise de alguns momentos decisivos da história do partido.

${ }^{40}$ Cf. "Marxismo na economia brasileira”, de Guido Mantega (1995). O artigo destaca três períodos no marxismo brasileiro e estabelece uma linha evolutiva entre eles. O "materialismo primitivo" vigente até os anos 1940, inclusive na obra de Caio Prado, teria sido suplantado, na década de 1950, pelo "materialismo funcionalista". Ambos foram superados pelo "materialismo dialético" dos cepalinos e dos membros do "Seminário Marx". O que essa teleologia apresenta como refinamento do marxismo brasileiro consistiu, na realidade, na progressiva subordinação dos esboços de uma teoria econômica marxista ao referencial conceitual de Weber, Keynes, Schumpeter e Kalecki.

Não deixa de ser curioso observar que Mantega sequer menciona seu livro sobre o tema, A economia política brasileira (1987), no qual se encontram análises bem mais pertinentes sobre o pensamento econômico marxista brasileiro.

41 Cf. "Origens do marxismo filosófico no Brasil: José Arthur Giannotti”, de Paulo Eduardo Arantes (1995). O artigo aborda apenas a obra de José Arthur Giannotti - um dos expoentes do "Seminário Marx" e pioneiro do marxismo acadêmico paulistano, mas com escassa ascendência sobre a doutrina, a militância e as organizações marxistas. No último capítulo de seu livro sobre a filosofia da USP nos anos 1960, Um departamento francês de ultramar, Arantes (1994) comenta também a produção de Ruy Fausto e Emir Sader.

42 Cf. "Intelectuais do ISEB, esquerda e marxismo", de Caio Navarro Toledo (1998). Sobre o ISEB conferir ainda: do mesmo autor, ISEB: fábrica de ideologias (1977); Intelectuais e política no Brasil: a experiência do ISEB, organizado também por Caio Navarro Toledo (2005); A verdade sobre o ISEB, de Nelson Werneck Sodré (1978) e Os intelectuais e a política no Brasil: entre o povo e a nação, de Daniel Pécaut (1990). 
(um grupo informal de professores da Faculdade de Filosofia,Letras e Ciências Humanas (FFLCH) da Universidade de São Paulo (USP), reagrupados a partir de 1969 no Centro Brasileiro de Análise e Planejamento (CEBRAP), o artigo ressalta como seu traço decisivo, numa avaliação desmentida pelos fatos, o caráter apenas "teórico" do grupo. ${ }^{43}$

O destaque positivo concedido aos participantes do "Seminário Marx", presente também nos artigos temáticos sobre a filosofia e a economia marxistas, espelha as ilusões propiciadas na ocasião da publicação desses volumes pela ascensão à presidência da República de Fernando Henrique Cardoso, um intelectual declaradamente marxista. Esse episódio ilustra bem os riscos de uma determinação do território do marxismo que considere como critério de pertinência apenas a reivindicação de pertencimento a essa linhagem por parte de pessoas ou grupos.

O lugar mais adequado para inserir, numa história do marxismo, autores com posições políticas marcadamente liberais como José Arthur Giannotti e Fernando Henrique Cardoso - bem como alguns de seus "companheiros de viagem" - seria o compartimento reservado aos representantes da versão brasileira do "marxismo legal". Como se trata de um 농 movimento pouco conhecido, transcrevo uma : descrição clássica dessa tendência, feita por Eric Hobsbawm (1982, p. 84):

Na Rússia, paradoxalmente, o marxismo - além de constituir uma teoria alternativa em relação à posição revolucionária anticapitalista dos populistas (que, no entanto, haviam assimilado diversas análises marxistas sobre o capitalismo) - proporcionou certa justificação à missão histórica do capitalismo, numa postura que pode ser considerada de certo modo anômala na atmosfera ideológica geral do país. O marxismo representou, assim, a base para o curioso fenômeno dos "marxistas legais", que ressaltaram as realizações históricas positivas do capi-

${ }^{43} \mathrm{O}$ autor do artigo se deixou levar pela imagem construída pelos participantes do Seminário como forma de exacerbar a injustiça cometida pela ditadura militar na cassação de seus membros, ignorando o evidente contra-senso de apontar uma associação de marxistas como apolítica. talismo, abandonando a perspectiva de derrubá-lo. Entre o final do século XIX e o começo do século XX, chegou-se a uma espécie de reconciliação com a burguesia por parte de um restrito grupo de estudiosos que, se tivessem vivido na Europa central ou ocidental em lugar da Rússia, certamente se sentiriam muito mais à vontade declarando-se liberais e não marxistas.

A terceira das estratégias projetadas consistiria na análise, caso a caso, da produção teórica de cada um dos intelectuais comunistas mais representativos do período, esforço que não foi além de um único artigo, dedicado aos escritos político-partidários de Caio Prado Júnior. ${ }^{44}$ A ausência de ensaios sobre, entre outros, Nelson Werneck Sodré e Alberto Passos Guimarães ${ }^{45}$ justifica-se, mais uma vez, pela ausência de pesquisas encorpadas sobre suas obras. ${ }^{46}$

Uma vez patente o caráter incompleto dessas tentativas, os organizadores privilegiaram - acertadamente, tendo em vista os resultados - a encomenda a intelectuais capacitados (embora desprovidos do histórico de pesquisas anteriores no assunto) de artigos sobre a contribuição do marxismo para alguns dos principais tópicos da compreensão da sociedade brasileira. Os temas selecionados foram: (a) o debate historiográfico sobre a colonização e

${ }^{44}$ Cf. "Opinião pública e partidos políticos em algumas análises de conjuntura de Caio Prado Jr.", de Raimundo Santos (2000). Sobre Caio Prado Júnior, conferir História e ideal: ensaios sobre Caio Prado Júnior, organizado por Maria Angela D’Incao (1989); Diários políticos de Caio Prado Júnior: 1945 e Caio Prado Júnior: uma trajetória intelectual, de Paulo Teixeira Iumatti $(1998,2007)$; Entre a nação e a barbárie, de Plínio Arruda Sampaio Jr (1999); Sentimento do Brasil: Caio Prado Júnior, continuidades e mudanças no desenvolvimento da sociedade brasileira, de Rubem Murilo Leão Rêgo (2000); Caio Prado Jr. e a nacionalização do marxismo no Brasil, de Bernardo Ricupero (2000); Caio Prado Júnior na cultura política brasileira, de Raimundo Santos (2001); A dinâmica de um pensamento crítico: Caio Prado Júnior, 1928-1935, de Paulo Henrique Martinez (2008) e Caio Prado Júnior: o sentido da revolução, de Lincoln Secco (2008).

${ }^{45}$ Depois da edição do volume, foram publicados três livros sobre Nelson Werneck Sodré: Nelson Werneck Sodré na historiografia brasileira, Dicionário crítico Nelson Werneck Sodré, ambos organizados por Marcos Silva (2001, 2008), e Um olhar à esquerda: a utopia tenentista na construção do pensamento marxista de Nelson Werneck Sodré, de Paulo Ribeiro Cunha (2002).

${ }^{46} \mathrm{O}$ projeto de apresentar o "encontro dos intelectuais brasileiros, no século XX, com o marxismo", esboçado por Leandro Konder (1991), a partir da publicação na imprensa de 15 perfis, depois reunidos no livro Intelectuais brasileiros e marxismo, ainda não encontrou seguidores. 
os conceitos conexos de escravismo e capital mercantil; ${ }^{47}$ (b) a controvérsia sobre a presença e a combinação de diferentes modos de produção na gestação da forma capitalismo no Brasil;: ${ }^{48}$ (c) as teorias sobre o ritmo e o andamento da revolução burguesa no país; ${ }^{49}$ (d) a discussão sobre os obstáculos ao desenvolvimento nacional e à consolidação de um regime democrático; $;^{50}(\mathrm{e})$ as polêmicas atinentes à questão agrária e às tentativas de reforma no campo; ${ }^{51}$ (f) e, por fim, a "questão meridional" do Brasil, o atraso secular do Nordeste. ${ }^{52}$

Não deixa de causar perplexidade que tenha sido necessário recorrer a articulistas que não são propriamente especialistas nas questões abordadas justamente quando se tratava de acompanhar os pontos altos da teoria marxista no Brasil - quando ela não apenas redefine o arcabouço conceitual e o sentido da interpretação do país, mas também se desdobra como um capítulo brasileiro dentro do esforço mundial de atualização e ampliação da doutrina de Marx.

A mesma carência de pesquisas, patente na investigação acerca do impacto do marxismo nas teorias dedicadas à interpretação do Brasil, pode ser detectada, em grau ampliado, na área dos estudos sobre seu impacto no campo artístico. ${ }^{53}$ Tanto num caso como noutro,

${ }^{47}$ Cf. "Feudalismo, capital mercantil, colonização”, de Lígia Osório Silva (2002).

${ }^{48}$ Cf. "O dual, o feudal e o etapismo na teoria da revolução brasileira”, de Carlos Alberto Dória (1998). Para um comentário detalhado deste e dos outros artigos do terceiro volume, conferir "Questões do passado e do presente", de Ricardo Musse (2001).

${ }^{49}$ Cf. "A teoria da revolução burguesa: tentativa de particularização de uma revolução burguesa em processo", de Marcos Del Roio (2000). A maior parte do artigo concentra-se na exposição e no confronto entre as teorias da revolução desenvolvidas por Nelson Werneck Sodré, Caio Prado Júnior e Florestan Fernandes.

${ }^{50}$ Cf. "O programa nacional democrático: fundamentos e permanência”, de João de Quartim de Moraes (2000).

${ }^{51}$ Cf. "Luta por terra e organização dos trabalhadores rurais: a esquerda no campo nos anos 50 e 60", de Leonilde Servolo Medeiros (2000). O artigo, que cobre apenas as décadas de 1950 e 60, destaca as posições e intervenções do PCB.

Registre-se a ausência na coleção de um artigo sobre o MST, organização que atribui lugar central ao marxismo.

${ }^{52}$ Cf. "O Nordeste: 'problema nacional' para a esquerda”, de Carlos Alberto Dória (2000).

${ }^{53}$ Insuficiência reconhecida nos artigos sobre cultura da parte da dificuldade assenta-se no fato de que o objeto a ser investigado não pode se restringir aos indivíduos com filiação partidária em agrupamentos marxistas, uma fronteira que os pesquisadores, muitas vezes, mostram-se temerosos em ultrapassar. ${ }^{54}$

Apesar do reconhecimento público, os efeitos da disseminação do marxismo na arte brasileira ainda são subestimados. A vitalidade e brilho da arte modernista local, sua sintonia com os movimentos artísticos europeus e a preocupação simultânea com a revelação do Brasil, tornam-se incompreensíveis quando se desconsidera a ascendência do marxismo na cultura brasileira, sobretudo no período entre 1930 e 1980.

A lista de artistas que se depararam com a teoria ou se engajaram na prática política marxista em algum momento de sua trajetória é impressionante, agrupando muitos dos expoentes em cada área. Na ausência de um mapeamento mais preciso, relembro alguns dentre os nomes mais destacados:

Na literatura: Oswald de Andrade, Patrícia Galvão (Pagu), Mario de Andrade, Carlos Drummond de Andrade, Raquel de Quei-

coleção: "A política cultural dos comunistas”, de Celso Frederico (1998) e "Marxismo, cultura e intelectuais no Brasil”, de Antônio Albino Canelas Rubim (1998). O artigo de Frederico aborda dois dos principais pontos de clivagem do debate cultural no pós-1964, a avaliação da política global do PCB antes de 1964 e a querela do nacionalismo na arte. Rubim concentra seu estudo nos aparatos de divulgação do PCB: jornais, revistas e editoras.

Sobre a cultura de esquerda após 1964, conferir Vanguarda e subdesenvolvimento, de Ferreira Gullar (1969); "Cultura e política, 1964-1969", de Roberto Schwarz (1978); Teatro e política: Arena, Oficina e Opinião, de Edelcio Mostaço (1982); O nacional e o popular na cultura brasileira seminários, de Marilena Chaui (1982); O nacional e o popular na cultura brasileira - teatro, de José Arrabal e Mariângela Alves Lima (1983); O nacional e o popular na cultura brasileira - cinema, de Jean-Claude Bernardert e Maria Rita Galvão (1983); Teatro da militância: a intenção do popular no engajamento político, de Silvana Garcia (1990) e Em busca do povo brasileiro: artistas da revolução, do CPC à era da TV, de Marcelo Ridenti (2000).

Sobre a imprensa de esquerda conferir Jornalistas e revolucionários: Nos tempos da imprensa alternativa, de Bernardo Kucinski (1991) e O imaginário vigiado: $A$ imprensa comunista e o realismo socialista no Brasil, 1947-1953, de Dênis Moraes (1994).

${ }^{54}$ Exceções são os livros Ideologia da cultura brasileira (1933-1974), de Carlos Guilherme Mota (1977); As idéias socialistas no Brasil e Intelectuais brasileiros e marxismo, de Leandro Konder $(1996,1991)$ e Em busca do povo brasileiro: Artistas da revolução, do CPC à era da TV, de Marcelo Ridenti (2000). Conferir ainda Arte para quê? A preocupação social na arte brasileira, 1930-1970, de Aracy Amaral (1987) e Cultura e sociedade no Brasil, de Carlos Nelson Coutinho (1990). 
rós, Graciliano Ramos, Jorge Amado, Dionélio Machado, Érico Veríssimo, José Lins do Rêgo, João Cabral de Melo Neto, Vinicius de Moraes, Aníbal Machado, Rubem Braga, Bernardo Élis, Ferreira Gullar, Antonio Calado, Jorge Mautner, João Antônio, João Ubaldo Ribeiro, Ivan Ângelo, Marcio Souza e os críticos Astrojildo Pereira, Álvaro Lins, Otto Maria Carpeaux, Alfredo Bosi, Silviano Santiago, Luiz Costa Lima, Antonio Candido e seus discípulos Roberto Schwarz, Walnice Nogueira Galvão e João Luis Lafetá.

Nas artes plásticas: Di Cavalcanti, Tarcila do Amaral, Candido Portinari, Lívio Abramo, Flávio de Carvalho, Pancetti, Clóvis Graciano, Vasco Prado, Glauco Rodrigues, Carlos Scliar, Roberto Burle-Marx, Bruno Giorgi, Mário Gruber, Renina Katz, Mario Zanini, Waldemar Cordeiro, Mauricio Nogueira Lima, Antonio Henrique do Amaral, Carlos Zílio, Rubens Gerchman, Claudio Tozzi e os críticos Mario Pedrosa, Mário Schenberg, Ferreira Gullar e Aracy Amaral.

No cinema: Alberto Cavalcanti, Nelson Pereira dos Santos, Glauber Rocha, Leon Hirszman, Ruy Guerra, Joaquim Pedro de Andrade, Cacá Diegues, Arnaldo Jabor, Luís Sérgio Person, Walter Lima Jr., Maurice Capovilla, Fernando Cony Campos, Eduardo Coutinho, Wladimir Carvalho, João Batista de Andrade e 농 os críticos Alex Viany, Walter Silveira, Paulo $\therefore$ Emilio Salles Gomes, Jean-Claude Bernardet e $\stackrel{\&}{\longrightarrow}$ Ismail Xavier.

No teatro: os dramaturgos Jorge Andrade, Ariano Suassuna, Oduvaldo Viana Filho, Gianfrancesco Guarnieri, Paulo Pontes, Dias Gomes, Consuelo de Castro, João das Neves; * os diretores Augusto Boal, José Celso Martinez a Correa, Flávio Rangel e o crítico Décio de Al-

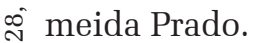

$\mathrm{Na}$ arquitetura: Oscar Niemayer, Villanova Artigas, Lina Bo Bardi e Sergio Ferro.

\section{$* * *$}

A partir dos anos 1960, a dispersão do marxismo, até então mais intensa na vida in- telectual, atinge em cheio as organizações partidárias. Em 1962, com a fundação do Partido Comunista do Brasil (PC do B), o PCB enfrenta sua primeira cisão desde a saída dos trotskistas da Oposição de Esquerda nos anos $1930 .{ }^{55}$ Após o golpe de 1964 esse movimento se amplifica com as dissensões que desembocaram na Aliança Libertadora Nacional (ALN) - comandada por Carlos Marighella e Joaquim Câmara Ferreira - e no Partido Comunista Brasileiro Revolucionário (PCBR), capitaneado por Apolônio de Carvalho, Jacob Gorender e Mário Alves.

Essa fragmentação se explica, em parte, pelo fascínio suscitado por novas formas de transição ao socialismo, os receituários heterodoxos oriundos do histórico das revoluções na China e em Cuba. No caso das dissidências posteriores a 1964, convém lembrar ainda que a consolidação do regime militar no Brasil fortaleceu a convicção de que a via democrática e nacional estava definitivamente encerrada e de que, portanto, a resistência antiimperialista só poderia ser levada adiante sob a forma da luta armada. ${ }^{56} \mathrm{O}$ predomínio dessa análise em diferentes espectros da militância marxista fez com que os outros partidos - a AP, a POLOP e o PC do B - também fossem submetidos a idênticos processos de desintegração. ${ }^{57}$

A derrota da resistência armada, consumada entre 1973 e 1974, favoreceu a emergência de novas formas de luta. Com a desestruturação dos partidos e das organizações políti-

${ }^{55}$ Esse processo, assim como a trajetória posterior do PC do B até 2001, foi tratado na coleção em "Partido Comunista do Brasil: definições ideológicas e trajetória política" por Jean Rodrigues Sales (2007).

56 Cabe ressaltar ainda o "voluntarismo político" da esquerda no período, tão bem caracterizado por Marco Aurélio Garcia (1986) em Contribuições para uma história da esquerda brasileira.

${ }^{57} \mathrm{O}$ sexto volume traz uma descrição precisa dessa cissiparidade, conferir "Esquerdas armadas urbanas: 19641974”, de Marcelo Ridenti (2007). Outros artigos da colecão contêm passagens esclarecedoras sobre a luta armada: "O maoísmo e a trajetória dos marxistas brasileiros", de Daniel Aarão Reis (2003) e "A influência da revolução cubana sobre a esquerda brasileira nos anos 1960", de Carlos Alberto Barão (2003).

Os livros mais importantes sobre o tema são Combate nas trevas, de Jacob Gorender (1987); A revolução faltou ao

encontro: os comunistas no Brasil, de Daniel Aarão Reis (1990) e O fantasma da revolução brasileira, de Marcelo Ridenti (1993). 
cas de esquerda, o comportamento crítico e o engajamento militante transferem-se para uma série de movimentos, adjetivados em bloco como "sociais". ${ }^{58}$ Parte considerável do último livro da coleção é dedicada à apresentação e à análise da interconexão do marxismo com o feminismo, ${ }^{59}$ com o novo sindicalismo, ${ }^{60} \mathrm{e} \mathrm{com}$ a atuação secular dos cristãos. ${ }^{61}$

Em breve, porém, tão logo a conjuntura desanuviou, retoma-se a questão da representação política da classe operária. A Anistia, em 1979, possibilitou a reestruturação, na legalidade, dos dois partidos comunistas, o PCB e o PC do B. Este processo, no entanto, foi atropelado pela fundação do Partido dos Trabalhadores (PT), a partir de uma convergência entre o "novo sindicalismo", quadros remanescentes das organizações dissidentes dos anos 19601970 e cristãos socialistas. ${ }^{62} \mathrm{O}$ PT venceu, sem muita dificuldade, a disputa pela liderança política do conjunto do proletariado, travada inicialmente sob a forma de uma disputa sindical e, em seguida, no terreno eleitoral. ${ }^{63}$

${ }^{58}$ Uma teoria dos movimentos sociais foi ensaiada por Eder Sader (1988) em Quando novos personagens entram em cena.

${ }^{59}$ Cf. "O encontro marxismo-feminismo no Brasil”, de Maria Lygia Moraes (2007).

${ }^{60}$ Ver "O PCB, os trabalhadores e o sindicalismo na história recente do Brasil”, de Marco Aurélio Santana e Ricardo Antunes (2007).

${ }^{61}$ Cf. "Cristianismo da libertação e marxismo: de 1960 aos nossos dias”, de Michael Löwy (2007)..

${ }^{62} \mathrm{O}$ artigo sobre o PT em História do marxismo no Brasil: "O partido dos trabalhadores e a conquista do Estado: 1980-2005”, de Paulo Henrique Martinez (2007), preocupado em acompanhar a trajetória do partido até 2002 , relata apenas de forma sumária essa gênese. Para maiores esclarecimentos sobre os anos de formação do PT conferir: Sobre o PT, de Mario Pedrosa (1980); Da crítica do populismo à construcão do PT, de Raul Pont (1985); E agora, PT? - Caráter e identidade, organizado por Emir Sader (1986); PT: um projeto político para o Brasil, organizado por Carlos Nelson Coutinho (1989); Pensamento e ação: o PT e os rumos do socialismo, de Florestan Fernandes (1989); PT: a formação de um partido, 1979-1982, de Raquel Meneguello (1989); PT, a lógica da diferença: o Partido dos Trabalhadores na construção da democracia brasileira, de Margaret Keck (1991) e O PT, de André Singer (2001).

O artigo de Denise Rollemberg (2007), Debate no exilo: em busca da renovação, no sexto volume da coleção, reconstitui a discussão no exílio entre os marxistas, elo importante na transição da militância de esquerda das facções armadas para um partido de massas.

${ }^{63} \mathrm{O}$ artigo de Marco Aurélio Santana e Ricardo Antunes (2007) "O PCB, os trabalhadores e o sindicalismo na história recente do Brasil" reconstitui minuciosamente a disputa pela hegemonia no movimento sindical entre PT e PCB, destacan-
A necessidade de se diferenciar dos partidos comunistas - resultante do conflito pela hegemonia na esquerda brasileira, mas vitaminada também por um anseio autêntico em evitar os erros do passado -, fez com que o PT construísse uma auto-imagem na qual predomina o tópico da "ruptura". Seja devido a sua origem no sindicalismo e nos movimentos sociais, seja pelo esforço em constituir-se em partido de massas - com o concomitante repúdio do modelo da "vanguarda leninista" -, ou ainda por conta de sua recusa do programa político de frentes poli-classistas, associado ao empenho em transferir a ênfase da nação para a classe; os intelectuais do PT alardearam que constituíam uma configuração original na esquerda brasileira, sem termo de comparação com as experiências da tradição comunista. ${ }^{64}$

Essa “racionalização” tornou-se factível também graças à forma peculiar de inserção do marxismo no PT. Embora seu processo de fundação tenha seguido quase que literalmente a descrição feita por Marx no Manifesto do Partido Comunista acerca da "organização dos proletários em classe, e com isso em partido político”, o PT nunca adotou formalmente o marxismo. A co-habitação no partido de marxistas e não-marxistas impediu também - apesar da proliferação de debates, seminários e cartas de intenção - a definição de um modelo de socialismo a ser proposto à sociedade brasileira. $\mathrm{O}$ marxismo, no entanto, se fez presente, não só na terminologia de seus documentos e resoluções, mas também no arsenal de suas opções e ações políticas.

O PT vivenciou, ao longo de suas três décadas de existência, o mesmo dilema recorrente na história das organizações marxistas no Brasil, sintetizado na indagação - a transformação da sociedade deve ser buscada

do a insistência da direção do Partido Comunista numa política de frente democrática com a burguesia nacional.

${ }^{64}$ Uma rara exceção foi Francisco de Oliveira (1996) que, num artigo notável, "Qual é a do PT?", salientou a continuidade da experiência petista em relação à linhagem da esquerda brasileira. 
dentro ou fora da ordem capitalista? ${ }^{65} \mathrm{~A}$ deliberação, de início tateante, depois resoluta, a favor da conciliação entre capital e trabalho; a atenuação das vertentes anticapitalistas; a prevalência da nação ante a classe, tudo isso compõe um novo cenário que recapitula tanto a trajetória trilhada pelo PCB, sobretudo no decênio 1954-1964, como os caminhos adotados pelos partidos da Segunda Internacional no início do século XX. ${ }^{66}$

A adoção pelo PT de um programa democrático-nacional, premissa de sua ascensão, pela via eleitoral, ao poder, foi facilitada por sua recusa, desde a fundação, de qualquer forma de alinhamento externo, típica de uma era de refluxo do internacionalismo, mas também resultante do declínio e fim da experiência histórica do socialismo de Estado no Leste europeu que sepultou as expectativas, já debilitadas, de desenvolvimento nacional fora da ordem capitalista. ${ }^{67}$

A conquista do Estado pelo PT completa, com o anel político, o processo de integração do proletariado brasileiro. Trata-se de um movimento de longa duração, iniciado na década de 1930 com a legislação trabalhista

${ }^{65}$ A oscilação entre esses termos, o paulatino predomínio do "consentimento" sobre a "negação" nos documentos e resoluções do PT e na "consciência de classe" da militância petista foi rastreado por Mauro Luis Iasi (2006),

$\llcorner 0$ em As metamorfoses da consciência de classe: o PT entre

○ a negação e o consentimento. Conferir também $O$ partido

․ dos trabalhadores e a conquista do Estado: 1980-2005, de $\therefore$ \& Paulo Henrique Martinez (2007).

$\stackrel{\measuredangle}{\bigcirc}{ }^{66}$ Embora seja arriscado comparar experiências históricas

‡ desenvolvidas em épocas e sociedades distintas, não há

$\Sigma$ como ignorar as semelhanças entre o percurso do PT e a

เి dinâmica da socialdemocracia europeia. Para uma descri-

† ção das aporias dos partidos de massas europeus confe-

\& rir Capitalismo e social-democracia, de Adam Przeworski + (1991).

$\stackrel{2}{2} 67$ A tensão entre um programa nacional e o internacio-

$\curvearrowright$ nalismo proletário manteve-se ao longo do itinerário do

¿ PT, sobretudo por conta do peso no interior do partido da

- presença de correntes trotskistas. Não foi casual que as

$\stackrel{\infty}{\sim}$ cisões que resultaram na formação do Partido Socialista

$>$ dos Trabalhadores Unificado (PSTU) e do Partido Socialis-

: mo e Liberdade (PSOL), concomitantes à ênfase petista na

opção nacionalista, tenham sido capitaneadas por grupos

$\stackrel{\pi}{\perp}$ trotskistas, atitude facilitada por sua posição refratária a

స్ formas de organização partidárias distintas do modelo da

" "vanguarda leninista".

Sobre o trotskismo nesse período conferir "O trotskismo

J no Brasil, 1966-2000”, de Dainis Karepovs e Murilo Leal ○ (2007).

Uma breve descrição dos partidos políticos que reivindicam o marxismo hoje se encontra em "Marxismo, socieda$\circlearrowleft$ de e partidos políticos hoje”, de Daniel Aarão Reis (2007). e previdenciária. Entre seus momentos decisivos, se destaca as greves operárias no ABC, em 1978-1979, anúncio simultâneo da exaustão da ditadura militar e da emergência de um novo sindicalismo.

No exercício do poder, o PT recuou de sua negação programática da tradição do PCB. ${ }^{68}$ A opção por um governo neodesenvolvimentista, a atualização do projeto nacional e popular reitera sua consonância com a experiência histórica do marxismo brasileiro, sobretudo aquela gestada em seu momento de maior impacto na sociedade local, no período 19541964. Mas o decisivo nessa escolha talvez seja a emergência, com o declínio do império norte-americano, de uma relativa desorganização do sistema inter-estatal capitalista, que parece abrir brechas para a mobilidade dos países da semi-periferia na até então congelada hierarquia das nações.

Recebido para publicação em 10 de setembro de 2013 Aceito em12 de fevereiro de 2015

\section{REFERÊNCIAS}

AARÃO REIS, Daniel. A revolução faltou ao encontro: os comunistas no Brasil. São Paulo, Brasiliense, 1990.

Entre reforma e revolução: a trajetória do Partido Comunista no Brasil entre 1943 e 1964. In: RIDENTI, Marcelo; AARÃ̃O REIS, Daniel (Orgs.). História do marxismo no Brasil, partidos e organizações dos anos 1920 aos 1960. Campinas: editora da Unicamp, v. 5, p. 73-108, 2002 .

Marxismo, sociedade e partidos políticos hoje. In: RIDENTI, Marcelo; AARÃO REIS, Daniel (Orgs.). História do marxismo no Brasil, partidos e movimentos após os anos 1960. Campinas: editora da Unicamp, v. 6, p. 439461. 2007.

O maoísmo e a trajetória dos marxistas brasileiros. In: QUARTIM DE MORAES, João; AARÃO REIS, Daniel (Orgs.). História do marxismo no Brasil, o impacto das revoluçôes. Campinas: editora Unicamp, $2^{\text {a }}$ ed., v. 1, p. 161-197. 2003.

ABRAMO, Fúlvio; KAREPOVS, Dainis (Orgs.). Na contracorrente da história: documentos da Liga Comunista Internacionalista, 1930-1933. São Paulo: Brasiliense, 1987.

AMADO, Jorge. Vida de Luiz Carlos Prestes: o cavaleiro da esperança. São Paulo: Martins, 1945.

AMARAL, Aracy. Arte para quê?: a preocupação social na arte brasileira, 1930-1970, $2^{\text {a }}$. Ed. São Paulo: Nobel, 1987.

${ }^{68}$ Cf. A viagem quase redonda do PT de Luiz Werneck Vianna (2009). 
ANDREUCCI, Franco. A difusão e a vulgarização do marxismo. In: HOBSBAWM, Eric (Org.). História do marxismo. Rio de Janeiro: Paz e Terra, v. 2, p. 15-73. 1982.

ANTUNES, Ricardo. Classe operária, partidos e sindicatos no Brasil: da Revolução de 30 até a Aliança Nacional Libertadora. São Paulo: Cortez, 1982.

ARANTES, Aldo; LIMA, Haroldo. História da Ação Popular, da JUC ao PC do B. São Paulo: Editora Alfa-ômega, 1984.

ARANTES, Paulo Eduardo. Origens do marxismo filosófico no Brasil: José Arthur Giannotti. In: QUARTIM DE MORAES, João (Org.). História do marxismo no Brasil, os influxos teóricos. Campinas: editora da Unicamp, v. 2 , p. 127-186. 1995.

Um departamento francês de ultramar. São Paulo Paz e Terra, 1994

ARRABAL, José; LIMA, Mariângela Alves. O nacional e o popular na cultura brasileira - teatro. São Paulo: Brasiliense, 1983.

ARRIGHI, Giovanni. A ilusão do desenvolvimento. Petrópolis: Vozes, 1997.

BANDEIRA, Luiz Alberto Muniz. $O$ ano vermelho. A revolução russa e seus reflexos no Brasil. Rio de Janeiro: Civilização Brasileira, 1967.

BARÃO, Carlos Alberto. A influência da revolução cubana sobre a esquerda brasileira nos anos 1960. In: QUARTIM DE MORAES, João; AARÃO REIS, Daniel (Orgs.). Histório do marxismo no Brasil, o impacto das revoluções. Campinas: editora Unicamp, 2a . ed., v. 1, p. 229-278. 2003.

BASTOS, Abguar. Prestes e a revolução social. São Paulo: Hucitec, 1986.

BATALHA, Claudio H. M. A difusão do marxismo e os socialistas brasileiros na virada do século XIX. In: QUARTIM DE MORAES, João (Org.). História do marxismo no Brasil, os influxos teóricos. Campinas: editora da Unicamp, v. 2, p. 9-41, 1995.

(Org.). Dicionário do movimento operário. São Paulo: Fundação Perseu Abramo, 2009.

BEOZZO, José Oscar. Cristãos na universidade e na política: história da JUC e da AP. Petrópolis: Vozes, 1984.

BERNARDET, Jean-Claude; GALVÃO, Maria Rita. O nacional e o popular na cultura brasileira - cinema. São Paulo: Brasiliense, 1983.

BICALHO, Luiz de Carvalho (Org.). PCB: processo de cassação de registro (1947). Belo Horizonte: Aldeia global, 1980.

BOAVENTURA, Maria Eugenia. O salão e a selva. Uma biografia intelectual de Oswald de Andrade. São Paulo: Ex-Libris/Unicamp, 1996.

BRANDÃO, Gildo Marçal. A esquerda positiva: as duas almas do partido comunista (1920-1964). São Paulo: Hucitec, 1992.

BRANDÃO, Octávio. Agrarismo e industrialismo. São Paulo: Anita Garibaldi, 2006.

CARONE, Edgar. O PCB, de 1922 a 1943. São Paulo: Difel, 1982.

O PCB: 1943-1964. São Paulo: Difel, 1982.

CHAUI, Marilena. O nacional e o popular na cultura brasileira - seminários. São Paulo: Brasiliense, 1982.

CLICOTE, Ronald H. O Partido Comunista Brasileiro: conflito e integração. Rio de Janeiro, Graal, 1982.

COGGIOLA, Osvaldo. O trotskismo no Brasil, 1928-1964. In: MAZZEO, Antonio Carlos; LAGOA, Maria Izabel (Orgs.). Corações vermelhos: os comunistas brasileiros no século XX. São Paulo: Cortez, p. 239-269, 2003.
COUTINHO, Carlos Nelson. Cultura e sociedade no Brasil. Belo Horizonte: Oficina de livros, 1990.

Gramsci no Brasil: recepção e usos. In: QUARTIM DE MORAES, João (Org.). História do marxismo no Brasil, teorias, interpretações. Campinas: editora da Unicamp, v. 3, p. 151-193. 1998.

(Org.). PT: um projeto político para o Brasil. São Paulo: Brasiliense, 1989.

CUNHA, Paulo Ribeiro. Um olhar à esquerda: a utopia tenentista na construção do pensamento marxista de Nelson Werneck Sodré. Rio de Janeiro: Revan, 2002.

DE DECCA, Edgar Salvadore. O silêncio dos vencidos. São Paulo: Brasiliense, 1982.

DEL ROIO, Marcos. A classe operária na revolução burguesa: a política de alianças do PCB (1928-1935). Belo Horizonte: Oficina de livros, 1990.

A teoria da revolução burguesa: tentativa de particularização de uma revolução burguesa em processo. In: QUARTIM DE MORAES, João; DEL ROIO, Marcos (Orgs.). História do marxismo no Brasil, visões do Brasil. Campinas: editora da Unicamp, v. 4, p. 73-134. 2000.

O impacto da revolução russa e da internacional comunista no Brasil. In: QUARTIM DE MORAES, João; AARÃO REIS, Daniel (Orgs.). História do marxismo no Brasil, o impacto das revoluções, Campinas: editora Unicamp, 2a . ed., v. 1, p. 51-107. 2007.

Os comunistas, a luta social e o marxismo (19201940). In: RIDENTI, Marcelo; AARAOO REIS, Daniel (orgs.). História do marxismo no Brasil, partidos e organizações dos anos 1920 aos 1960. Campinas: editora da Unicamp, v. 5, p. 11-72. 2002.

D’INCAO, Maria Angela (Org.). História e ideal: ensaios sobre Caio Prado Júnior. São Paulo: Brasiliense, 1989.

DÓRIA, Carlos Alberto. O dual, o feudal e o etapismo na teoria da revolução brasileira. In: QUARTIM DE MORAES, João (Org.). História do marxismo no Brasil, teorias, interpretações. Campinas: editora da Unicamp, v. 3, p. 245-297. 1998.

O Nordeste: "Problema nacional" para a esquerda”. In: QUARTIM DE MORAES, João; DEL ROIO, Marcos (Orgs.). História do marxismo no Brasil, visões do Brasil. Campinas: editora da Unicamp, v. 4, p. 271-291, 2000.

DULLES, John W. F. O comunismo no Brasil. Rio de Janeiro: Nova Fronteira, 1985.

FEIJÓ, Martin Cezar. O revolucionário cordial. Astrojildo Pereira e as origens de uma política cultural. São Paulo,: Boitempo, 2001.

FERREIRA, Jorge; AARÃO REIS, Daniel. As esquerdas no Brasil. Rio de Janeiro: Civilização Brasileira, v. 1, 2 e 3. 2007.

FERNANDES, Florestan. Pensamento e ação: o PT e os rumos do socialismo. São Paulo: Brasiliense, 1989.

FIORI, José Luís. O vôo da coruja: para reler o desenvolvimentismo brasileiro. Rio de Janeiro: Record, 2003.

FREDERICO, Celso. Presença de Lukács na política cultural do PCB e na Universidade. In: QUARTIM DE MORAES, João (Org.). História do marxismo no Brasil, os influxos teóricos. Campinas: editora da Unicamp, v. 2, pp. 187-228, 1995 .

A política cultural dos comunistas. In: QUARTIM DE MORAES, João (Org.). História do marxismo no Brasil, teorias, interpretações. Campinas: editora da Unicamp, v. 3, p. 337-372, 1998.

GARCIA, Marco Aurélio. Contribuições para uma 
história da esquerda brasileira. In: MORAES, Reginaldo; ANTUNES, Ricardo; FERRANTE, Vera (Orgs.). Inteligência brasileira. São Paulo: Brasiliense, p.193-223. 1986.

GARCIA, Silvana. Teatro da militância: a intenção do popular no engajamento político. São Paulo: Perspectiva, 1990.

GOMES DE SOUZA, Luiz Alberto. A JUC: Os estudantes católicos e a política. Petropolis: Vozes, 1984

GORENDER, Jacob. Combate nas trevas. São Paulo: Ática, 1987.

GULLAR, Ferreira. Vanguarda e subdesenvolvimento. Rio de Janeiro: Civilização Brasileira, 1969.

GUSTIN, Miracy Barbosa de Sousa; VIEIRA, Margarida Luiza de Matos. Semeando democracia: a trajetória do socialismo democrático no Brasil. Contagem: Palesa, 1995.

HAUPT, Georg. Marx e o marxismo. In: HOBSBAWM, Eric (Org.). História do marxismo. Rio de Janeiro: Paz e Terra, v. 1, p. 347-375. 1982.

HECKER, Alexandre. Socialismo sociável: história da esquerda democrática em São Paulo (1945-1964). São Paulo: editora da Unesp, 1998.

HOBSBAWM, Eric. A cultura européia e o marxismo entre o século XIX e o século XX. In: HOBSBAWM, Eric (Org.). História do marxismo. Rio de Janeiro: Paz e Terra, v. 2, p. 75-124. 1982. Terra, 1992

A era dos impérios (1875-1914). São Paulo: Paz e

IASI, Mauro Luis. As metamorfoses da consciência de classe: o PT entre a negação e o consentimento. São Paulo: Expressão Popular, 2006.

IUMATTI, Paulo Teixeira. Caio Prado Júnior: uma trajetória intelectual. São Paulo: Brasiliense, 2007.

Diários políticos de Caio Prado Júnior: 1945. São Paulo: Brasiliense, 1998.

KAREPOVS, Dainis. Luta subterrânea: o PCB em 19371938. São Paulo: Hucitec/Unesp, 2003.

LEAL, Murilo, O trotskismo no Brasil, 19662000. In: RIDENTI, Marcelo; AARÃO REIS, Daniel (Orgs.). História do marxismo no Brasil, partidos e movimentos após os anos 1960. Campinas: editora da Unicamp, v. 6, เ p. 153-237, 2007. brasileiros e suas organizaçóes políticas (1930-1966). In: $\because$ RIDENTI, Marcelo; AARÃO REIS, Daniel (Orgs.). História $\varangle$ do marxismo no Brasil, partidos e organizaçốes dos anos 을 1920 aos 1960. Campinas: editora da Unicamp, v. 5, p. 109-165, 2002

L $\quad$ :MARQUES NETO, José Castilho; LÖWY, Michael. Trotsky e o Brasil. In: QUARTIM DE MORAES, João (Org.). S' História do marxismo no Brasil, os influxos teóricos. Campinas: editora da Unicamp, v. 2, p. 229-254, 1995.

× KECK, Margaret. PT, a lógica da diferença: o Partido dos

\} \text { Trabalhadores na construção da democracia brasileira. }

¿ São Paulo: Ática, 1991.

$\stackrel{\sim}{\infty}$ KONDER, Leandro. A derrota da dialética. A recepção das $>$ idéias de Marx no Brasil, até o começo dos anos trinta. Rio î de Janeiro: Campus, 1988.

. As idéias socialistas no Brasil. São Paulo:

. Intelectuais brasileiros e marxismo. Belo Horizonte: Oficina de livros, 1991.

KUCINSKI, Bernardo. Jornalistas e revolucionários: nos tempos da imprensa alternativa. São Paulo: Scritta, 1991.

己े LEAL, Murilo. À esquerda da esquerda: trotskistas, comunistas e populistas no Brasil contemporâneo (19521966). São Paulo: Paz e Terra, 2004.

LÖWY, Michael. Cristianismo da libertação e marxismo: De 1960 a nossos dias. In: RIDENTI, Marcelo; AARÃO REIS, Daniel (Orgs.). História do marxismo no Brasil, partidos e movimentos após os anos 1960. Campinas: editora da Unicamp, v. 6, p. xy, 2007.

Marxismo e teologia da libertação. São Paulo: Cortez, 1991

MANTEGA, Guido. A economia política brasileira. Petrópolis: Vozes, 1987.

Marxismo na economia brasileira. In: QUARTIM DE MORAES, João. (Org.). História do marxismo no Brasil, os influxos teóricos. Campinas: editora da Unicamp, v. 2, p. 103-125, 1995.

MARANHÃO, Ricardo. Sindicatos e democratização. São Paulo: Brasiliense, 1979.

MARINI, Ruy Mauro. Dialética da dependência. Petrópolis: Vozes, 2000.

MARQUES NETO, José Castilho (Org.). Mário Pedrosa e o Brasil. São Paulo: Fundação Perseu Abramo, 2001.

Solidão revolucionária: Mário Pedrosa e as origens do trotskismo no Brasil. Rio de Janeiro: Paz e Terra, 1993.

MARTINEZ, Paulo Henrique. A dinâmica de um pensamento crítico: Caio Prado Júnior, 1928-1935. São Paulo: Edusp, 2008.

O partido dos trabalhadores e a conquista do Estado: 1980-2005. In: RIDENTI, Marcelo; AARÄO REIS, Daniel (Orgs.). História do marxismo no Brasil, partidos e movimentos após os anos 1960. Campinas: editora da Unicamp, v. 6, pp. 239-288, 2007.

MAZZEO, Antonio Carlos. Sinfonia inacabada: a política dos comunistas no Brasil. São Paulo: Boitempo, 1999.

MEDEIROS, Leonilde Servolo. Luta por terra e organização dos trabalhadores rurais: a esquerda no campo nos anos 50 e 60. In: QUARTIM DE MORAES, João; DEL ROIO, Marcos (Orgs.). História do marxismo no Brasil, visões do Brasil. Campinas: editora da Unicamp, v. 4, p. 229-269, 2000.

MENEGUELLO, Raquel. PT: a formação de um partido, 1979-1982. São Paulo: Paz e Terra, 1989.

MORAES, Dênis. O imaginário vigiado: a imprensa comunista e o realismo socialista no Brasil, 1947-1953. Rio de Janeiro: José Olympio, 1994.

- VIANA, Francisco. Prestes: lutas e autocríticas. Petrópolis: Vozes, 1982.

MORAES, Maria Lygia. O encontro marxismo-feminismo no Brasil. In: RIDENTI, Marcelo; AARÃO REIS, Daniel (Orgs.). História do marxismo no Brasil, partidos e movimentos após os anos 1960. Campinas: editora da Unicamp, v. 6, p. 341-373, 2007.

MORAES FILHO, Evaristo. A proto-história do marxismo no Brasil. In: QUARTIM DE MORAES, João; AARÃO REIS, Daniel (Orgs.). História do marxismo no Brasil, o impacto das revoluções Campinas: editora da Unicamp, $2^{\mathrm{a}}$. ed., v. 1, p. 11-49, 2007.

O socialismo brasileiro. Brasília: Instituto Teotônio Vilela, 1998.

MOSTAÇO, Edelcio. Teatro e política: Arena, Oficina e Opinião. São Paulo: Proposta editorial, 1982.

MOTA, Carlos Guilherme. Ideologia da cultura brasileira (1933-1974). São Paulo: Ática, 1977.

MUSSE, Ricardo. O legado de Marx no Brasil. In: Revista Estudos Avançados. São Paulo: IEA, nº. 63, p. 327-333, 2008. 
O primeiro marxista. In: BOITO JUNIOR, Armando et al. (Org.). A obra teórica de Marx. São Paulo: Xamã/ IFCH-Unicamp, p. 81-89, 2000.

Questões do passado e do presente. In: NASCIMENTO, Milton Meira (Org.). Jornal de resenhas. São Paulo: Discurso editorial, v. 2, p. 1278-9, 2001.

OLIVEIRA, Francisco. No silêncio do pensamento único: intelectuais, marxismo e política no Brasil. In: NOVAES, Adauto (Org.). O silêncio dos intelectuais. São Paulo: Companhia das Letras, p. 293-305, 2006.

Qual é a do PT?. In: SADER, Emir (Org.). E agora, $\overline{P T}$ ? - Caráter e identidade. São Paulo: Brasiliense, p. 9-34, 1996.

OSÓRIO SILVA, Lígia. Feudalismo, capital mercantil, colonização. In: QUARTIM DE MORAES, João; DEL ROIO, Marcos (Orgs.). História do marxismo no Brasil, visões do Brasil. Campinas: editora da Unicamp, v. 4, p. 11-72, 2000.

PACHECO, Eliézer. O partido comunista brasileiro: 19221964. São Paulo: editora Alfa-ômega, 1984.

PÉCAUT, Daniel. Os intelectuais e a política no Brasil: entre o povo e a nação. São Paulo: Ática, 1990.

PEDROSA, Mario. Sobre o PT. São Paulo: Ched Editorial, 1980.

PEREIRA, Astrojildo. Construindo o PCB (1922-1924). São Paulo: editora Ciências Humanas, 1980.

Formação do PCB (1922-1928). Rio de Janeiro: editora Vitória, 1962. Alfa-Ömega, 1979

Ensaios históricos e políticos. São Paulo: editora

PINHEIRO, Paulo Sérgio. Estratégias da ilusão: a revolução mundial e o Brasil, 1922-1935. São Paulo: Companhia das Letras, 1991.

Política e trabalho no Brasil: dos anos vinte a 1930. Rio de Janeiro: Paz e Terra, 1975.

; HALL, Michael. A classe operária no Brasil, documentos (1989 a 1930). São Paulo: editora Alfa-Ômega, 1979.

POMAR, Pedro Estevam da Rocha. A democracia intolerante: Dutra, Adhemar e a repressão ao Partido Comunista (1946-1959). São Paulo: Imprensa Oficial do Estado/Arquivo do Estado, 2002.

PONT, Raul. Da crítica do populismo à construção do PT. Porto alegre: Seriema, 1985.

PRESTES, Anita Leocadia. Da insurreição armada (1935) à "União Nacional" (1938-1945): a virada tática na política do PCB. São Paulo: Paz e Terra, 2001.

Luiz Carlos Prestes e a Aliança Nacional Libertadora: os caminhos da luta antifascista no Brasil (1934-1935). Petrópolis: Vozes, 1997.

PRZEWORSKI, Adam. Capitalismo e social-democracia. São Paulo: Companhia das Letras, 1991.

QUARTIM DE MORAES, João. A esquerda militar no Brasil: da conspiração republicana à república dos tenentes. São Paulo: Siciliano, 1991

A esquerda militar no Brasil: da Coluna à Comuna. São Paulo: Siciliano, 1994.

A evolução da consciência política dos marxistas brasileiros. In: QUARTIM DE MORAES, João. (Org.). História do marxismo no Brasil, os influxos teóricos. Campinas: editora da Unicamp, v. 2, p. 43-102, 1995.

A influência do leninismo de Stálin no comunismo brasileiro. In: QUARTIM DE MORAES, João; AARÃO REIS, Daniel (Orgs.). História do marxismo no Brasil, o impacto das revoluções. Campinas: editora da Unicamp, v. 1, p. 109-160, 2003.
Concepções comunistas no Brasil democrático: esperanças e crispações. In: QUARTIM DE MORAES, João (Org.). História do marxismo no Brasil, teorias, interpretações. Campinas: editora da Unicamp, v. 3, p. 197-244, 1998.

O programa nacional democrático: fundamentos e permanência. In: QUARTIM DE MORAES, João; DEL ROIO, Marcos (Orgs.). História do marxismo no Brasil, visões do Brasil. Campinas: editora da Unicamp, v. 4, p. 161-227, 2000

RÊGO, Rubem Murilo Leão. Sentimento do Brasil: Caio Prado Júnior, continuidades e mudanças no desenvolvimento da sociedade brasileira. Campinas: editora da Unicamp, 2000.

RICUPERO, Bernardo. Caio Prado Jr. e a nacionalização do marxismo no Brasil. São Paulo: editora 34, 2000.

RIDENTI, Marcelo. Ação Popular: cristianismo e marxismo. In: RIDENTI, Marcelo; AARÃO REIS, Daniel (Orgs.). História do marxismo no Brasil, partidos e organizaçóes dos anos 1920 aos 1960. Campinas: editora da Unicamp, v. 5, p. 227-302, 2002.

. Em busca do povo brasileiro: artistas da revolução,

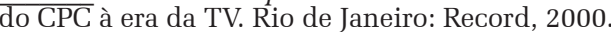

Esquerdas armadas urbanas: 1964-1974. In: RIDENTI, Marcelo; AARÃO REIS, Daniel (Orgs.). História do marxismo no Brasil, partidos e movimentos após os anos 1960. Campinas: editora da Unicamp, v. 6, p. 105151, 2007.

O fantasma da revolução brasileira. São Paulo: Unesp, 1993.

ROLLEMBERG, Denise. Debate no exilo: em busca da renovação. In: RIDENTI, Marcelo; AARÃO REIS, Daniel (Orgs.). História do marxismo no Brasil, partidos e movimentos após os anos 1960. Campinas: editora da Unicamp, v. 6, p. 291-339, 2007.

RUBIM, Antônio Albino Canelas. Marxismo, cultura e intelectuais no Brasil”. In: QUARTIM DE MORAES, João (Org.). História do marxismo no Brasil, teorias, interpretações, Campinas: editora da Unicamp, v. 3, p. 373-469, 1998.

SADER, Eder. Quando novos personagens entram em cena. São Paulo: Paz e Terra, 1988.

(Org.). E agora, PT? - Caráter e identidade. São Paulo: Brasiliense, 1986.

; SANTOS, Theotônio (Orgs.). A América Latina e os desafios da globalização: ensaios em homenagem a Ruy Mauro Marini. São Paulo: Boitempo, 2009.

SAES, Décio. O impacto da teoria althusseriana da história na vida intelectual brasileira. In: QUARTIM DE MORAES, João (Org.), História do marxismo no Brasil, teorias, interpretações Campinas: editora da Unicamp, v. 3, p. 13150, 1998.

SALES, Jean Rodrigues. Partido Comunista do Brasil: definicões ideológicas e trajetória política. In: RIDENTI, Marcelo; AARÃO REIS, Daniel (Orgs.). História do marxismo no Brasil, partidos e movimentos após os anos 1960. Campinas: editora da Unicamp, v. 6, p. 63-103, 2007.

SAMPAIO JR., Plínio Arruda. Entre a nação e a barbárie. Petrópolis: Vozes, 1999.

SANTANA, Marco Aurélio; ANTUNES, Ricardo. O PCB, os trabalhadores e o sindicalismo na história recente do Brasil. In: RIDENTI, Marcelo; AARÃO REIS, Daniel (Orgs.). História do marxismo no Brasil, partidos e movimentos após os anos 1960. Campinas: editora da Unicamp, v. 6, p. $375-410,2007$

SANTOS, Raimundo. Caio Prado Júnior na cultura política brasileira. Rio de Janeiro: Mauad, 2001. 
Crise e pensamento moderno no PCB dos anos 50. In: QUARTIM DE MORAES, João; AARÃO REIS, Daniel (Orgs.), História do marxismo no Brasil, o impacto das revoluções. Campinas: editora da Unicamp, $2^{\mathrm{a}}$. ed., v. 1 , p. 199-228, 2003.

Opinião pública e partidos políticos em algumas análises de conjuntura de Caio Prado Jr.. In: QUARTIM DE MORAES, João; DEL ROIO, Marcos (Orgs.). História do marxismo no Brasil, visões do Brasil. Campinas: editora da Unicamp, v. 4, p. 293-334, 2000.

SCHWARZ, Roberto. Cultura e política, 1964-1969. In: $O$ pai de família e outros estudos. Rio de Janeiro: Paz e Terra, p. 61-92, 1978.

SECCO, Lincoln. Caio Prado Júnior: o sentido da revolução. São Paulo: Boitempo, 2008.

SEGATO, José Antonio. Reforma e revolução: as vicissitudes políticas do PCB, 1954-1964. Rio de Janeiro: Civilização Brasileira, 1995.

SIGRIST, José Luiz. A JUC no Brasil, evolução e impasse de uma ideologia. São Paulo: Cortez, 1982.

SILVA, Angelo José. Tempo de fundadores. In: QUARTIM DE MORAES, João; DEL ROIO, Marcos (Orgs.). História do marxismo no Brasil. Visões do Brasil. Campinas: editora da Unicamp, v. 4, p. 135-159, 2000.

SILVA, Hélio. 1935: a revolta vermelha. Rio de Janeiro: Civilização Brasileira, 1969.

SILVA, Marcos (Org.). Dicionário crítico Nelson Werneck Sodré. Rio de Janeiro: editora UFRJ, 2008.

(Org.). Nelson Werneck Sodré na historiografia brasileira. Bauru: Edusc, 2001.

SINGER, André. O PT. São Paulo: Publifolha, 2001.

SODRÉ, Nelson Werneck. A intentona comunista de 1935. Porto Alegre: Mercado Aberto, 1986. 1978. A verdade sobre o Iseb. Rio de Janeiro: Avenir, 1984

Contribuição à história do PCB. São Paulo: Global,
TAVARES, José Nilo (Org.). Novembro de 1935: meio século depois. Petrópolis: Vozes, 1985

TOLEDO, Caio Navarro. Intelectuais do Iseb, esquerda e marxismo. In: QUARTIM DE MORAES, João (Org.). História do marxismo no Brasil, teorias, interpretaçôes. Campinas: editora da Unicamp, v. 3, p. 299-336, 1998.

(Org.). Intelectuais e política no Brasil: a experiência do ISEB. Rio de Janeiro: Revan, 2005.

. Iseb: fábrica de ideologias. São Paulo: Ática, 1977.

TRASPADINI, Roberta; STEDILE, João Pedro (Orgs.). Ruy Mauro Marini: vida e obra. São Paulo: Expressão Popular. 2005 .

VIANNA, Marly. Revolucionários de 1935: sonho e realidade. São Paulo: Companhia das Letras, 1992.

VIEIRA, Margarida Luiza de Matos. O Partido Socialista Brasileiro e o marxismo (1947-1965). In: RIDENTI, Marcelo; AARÃO REIS, Daniel (Orgs.), História do marxismo no Brasil, partidos e organizações dos anos 1920 aos 1960. Campinas: editora da Unicamp, v. 5, p. 167-196, 2002.

VINHAS, Moisés. O Partidão: a luta por um partido de massas (1922-1974). São Paulo: Hucitec, 1982.

WALLERSTEIN, Immanuel. Capitalismo histórico e civilização capitalista. Rio de Janeiro: Contraponto, 2001.

WERNECK VIANNA, Luiz. A viagem quase redonda do PT. In: Jornal de Resenhas. São Paulo: Discurso editorial, n. 3, p. 12-13, 2009.

Paz e Terra, 1976.

Liberalismo e sindicato no Brasil. Rio de Janeiro:

ZAIDAN FILHO, Michel. Comunistas em céu aberto, 19221930. Belo Horizonte: Oficina de livros, 1989.

O PCB e a Internacional Comunista: 1922-1929. São Paulo: Vértice, 1988.

PCB (1922-1929): na busca das origens de um marxismo nacional. São Paulo: editora Global, 1989. 


\section{THE ADVENTURES OF MARXISM IN BRAZIL}

\author{
Ricardo Musse
}

The thinking on the importance and the place of Marxism in Brazilian society, be it in political and social life, be it in the intellectual and cultural output, has gained an outstanding path with the completion of the collective work History of Marxism in Brazil. An inventory, even a precarious one, of its gaps and overlaps also allows for an overview of the bibliographic output on Brazilian Marxism. Starting from this, it becomes possible to highlight structures and trends in its historical development.

Keywords: Brazilian Marxism. Communist Party of Brazil. Workers' Party (Brazil). History of Marxism in Brazil.

\section{LES AVENTURES DU MARXISME AU BRÉSIL}

\author{
Ricardo Musse
}

La réflexion concernant l'importance et la place du marxisme dans la société brésilienne - que ce soit dans la vie politique et sociale ou dans la production intellectuelle et culturelle - a acquis une place privilégiée grâce à la conclusion de l'ouvrage collectif Histoire du marxisme au Brésil. Un inventaire de ses lacunes et de ses chevauchements qui, même s'il reste précaire, permet de faire un bilan de la production bibliographique sur le marxisme brésilien. Il est alors possible de mettre en évidence les structures et les tendances de son développement historique.

Mots-CLÉs: Marxisme brésilien. Parti Communiste du Brésil (PCB). Parti des Travailleurs (PT). Histoire du marxisme au Brésil.

Ricardo Musse - Doutor em filosofia. Professor associado da Universidade de São Paulo, Faculdade de Filosofia Letras e Ciências Humanas, Departamento de Sociologia. Tem experiência em pesquisas e docência nas áreas de sociologia e de filosofia, com ênfase em teoria sociológica, atuando principalmente nos temas: teoria crítica da sociedade, sociologia do marxismo, teoria social, sociologia e filosofia alemã. Publicações recentes: Crédito à morte. Critica Marxista (São Paulo), v. 38, p. 157-159, 2014; Para além de uma geografia do capital. Sociologia \& Antropologia, v. 04, p. 55-69, 2014. Antes de História e consciência de classe. Estudos Avançados (USP. Impresso), v. 27, p. 291-300, 2013. 
